\title{
Antimicrobial and antibiofilm potentials of cinnamon oil and silver nanoparticles against Streptococcus agalactiae isolated from bovine mastitis: new avenues for countering resistance
}

\author{
Norhan K. Abd El-Aziz ${ }^{1 *}$ (D), Ahmed M. Ammar ${ }^{1}$, El-sayed Y. M. El-Naenaeey ${ }^{1}$, Hend M. El Damaty²,
} Asmaa A. Elazazy ${ }^{3}$, Ahmed A. Hefny ${ }^{4}$, Asmaa Shaker ${ }^{5}$ and Ibrahim E. Eldesoukey ${ }^{6}$

\begin{abstract}
Background: Streptococcus agalactiae (S. agalactiae) is a contagious pathogen of bovine mastitis. It has financial implications for the dairy cattle industry in certain areas of the world. Since antimicrobial resistance increases in dairy farms, natural antimicrobials from herbal origins and nanoparticles have been given more attention as an alternative therapy. Hence, this study reported the antimicrobial and antibiofilm potentials of cinnamon oil, silver nanoparticles (AgNPs), and their combination against multidrug-resistant (MDR) S. agalactiae recovered from clinical bovine mastitis in Egypt.

Results: Our findings revealed that 73\% (146/200) of the examined milk samples collected from dairy cows with clinical mastitis were infected with Streptococci species. Of these, 9.59\% (14/146) were identified as S. agalactiae and categorized as MDR. S. agalactiae isolates expressed four virulence genes ( $H y l, c y \mid E, s c p B$, and $I m b)$ and demonstrated an ability to produce biofilms. Cinnamon oil showed high antimicrobial (MICs $\leq 0.063 \mu \mathrm{g} / \mathrm{mL})$ and antibiofilm $\left(\mathrm{MBIC}_{50}=\right.$ $4 \mu \mathrm{g} / \mathrm{mL}$ ) potentials against planktonic and biofilms of S. agalactiae isolates, respectively. However, AgNPs showed reasonable antimicrobial (MICs $\leq 16 \mu \mathrm{g} / \mathrm{mL})$ and relatively low antibiofilm $\left(\mathrm{MBIC}_{50}=64 \mu \mathrm{g} / \mathrm{mL}\right)$ activities against screened isolates. Synergistic antimicrobial or additive antibiofilm interactions of cinnamon oil combined with AgNPs were reported for the first time. Scanning electron microscope (SEM) analysis revealed that biofilms of S. agalactiae isolates treated with cinnamon oil were more seriously damaged than observed in AgNPs cinnamon oil combination. Moreover, reverse transcriptase quantitative polymerase chain reaction (RT-qPCR) showed that cinnamon oil exerted a remarkable down-regulation of pili biosynthesis genes (pilA and pilB) and their regulator (rogB) against S. agalactiae biofilms, meanwhile the AgNPs cinnamon oil combination demonstrated a lower efficacy.

(Continued on next page)
\end{abstract}

*Correspondence: norhan_vet@hotmail.com; nourhan_vet@zu.edu.eg

'Department of Microbiology, Faculty of Veterinary Medicine, Zagazig University, Zagazig, Sharkia 44511, Egypt

Full list of author information is available at the end of the article

C C The Author(s). 2021 Open Access This article is licensed under a Creative Commons Attribution 4.0 International License, which permits use, sharing, adaptation, distribution and reproduction in any medium or format, as long as you give appropriate credit to the original author(s) and the source, provide a link to the Creative Commons licence, and indicate if changes were made. The images or other third party material in this article are included in the article's Creative Commons licence, unless indicated otherwise in a credit line to the material. If material is not included in the article's Creative Commons licence and your intended use is not permitted by statutory regulation or exceeds the permitted use, you will need to obtain permission directly from the copyright holder. To view a copy of this licence, visit http://creativecommons.org/licenses/by/4.0/. The Creative Commons Public Domain Dedication waiver (http://creativecommons.org/publicdomain/zero/1.0/) applies to the data made available in this article, unless otherwise stated in a credit line to the data. 


\begin{abstract}
(Continued from previous page)
Conclusions: This is an in vitro preliminary approach that documented the antibiofilm potential of cinnamon oil and the inhibitory activity of cinnamon oil and its combination with AgNPs against MDR S. agalactiae recovered from clinical mastitis. Further in vivo studies should be carried out in animal models to provide evidence of concept for implementing these alternative candidates in the treatment of dairy farms infected by streptococcal mastitis in the future.
\end{abstract}

Keywords: Mastitis, Cinnamon oil, Silver nanoparticles, Antimicrobial activity, Antibiofilm potential

\section{Background}

Streptococcus agalactiae (S. agalactiae), group B streptococcus (GBS), is a Gram-positive, non-motile, non-spore former, encapsulated, and facultative aerobic bacteria [1]. It is an obligate pathogen of the mammary gland, but it can persist for a short time on milkers' hands, milking machines, or teat skin resulting in cow-to-cow transmission during milking [2].

Bovine mastitis caused by $S$. agalactiae has veterinary and economic importance in certain areas of the world. It causes substantial financial losses due to lower milk yield, decreased milk quality, and high numbers of deaths or culling of infected animals [3]. An eradication strategy was implemented to decrease the incidence of $S$. agalactiae mastitis in numerous European countries. However, its reemergence was denoted in China [4], Norway [5], Denmark, and several Scandinavian countries [6]. In Egypt, $S$. agalactiae was recently detected in cows diagnosed with clinical mastitis $[7,8]$.

Numerous studies have evaluated the ability of Streptococcus species to produce biofilms $[9,10]$. Biofilm-producing bacteria are more likely to sustain hostile environments. They can be better protected from the action of the host immune system while becoming less sensitive to the antibiotic or disinfectant activity [11, 12].

Antimicrobial therapy remains the foremost strategy for combating mastitis in dairy cows [13]. Based on previously published reports regarding the resistance of $S$. agalactiae causing clinical mastitis to multiple antimicrobials either in Egypt (e.g., lincomycin, clindamycin, erythromycin, amoxicillin, and penicillin) [7] or abroad [14], we precisely found a necessity to explore an alternative or adjunct to the antimicrobials for the treatment of mastitis.

Medicinal plants, with their well-established history, are an excellent natural product resource used as an alternative therapy. Cinnamon oil could be an interesting candidate owing to its antimicrobial properties [15]. The antimicrobial activity of cinnamon oil is attributed to cinnamaldehyde, which interacts with the microbial cell membrane by changing the proton motive force and evolving to cell lysis [16]. Moreover, silver nanoparticles (AgNPs) have been intensively reported as antimicrobial agents, including their use against multidrug-resistant
(MDR) bacteria [17]. The antimicrobial activity of AgNPs is thought to be mediated by (i) microbial cell adhesion, (ii) cell penetration, (iii) reactive oxygen species and free radical generation, and (iv) microbial signal transduction pathway modulation [18]. Studies exploring the virulence traits of Egyptian S. agalactiae isolates and their ability to produce biofilms are scarce. Thus, we sought to identify the virulence characteristics required for $S$. agalactiae causing bovine mastitis. Moreover, the antimicrobial and antibiofilm activities of cinnamon oil, AgNPs, and their combination were investigated as effective alternative approaches against MDR S. agalactiae isolates.

\section{Results}

Occurrence and phenotypic characteristics of S. agalactiae in clinical cases of bovine mastitis

Overall, 146 out of 200 (73\%) milk samples each corresponded to a single quarter of an individual clinically mastitic dairy cow originated from eight dairy herds across different Governorates in Egypt were found to be infected with Streptococci species. Of these, 14 (9.59\%) isolates were identified as $S$. agalactiae. Typical $S$. agalactiae isolates appeared as colorless dewdrop like colonies with a bluish hue and surrounded by a complete zone of hemolysis on Edward's media. Criteria such as negative reactions with the catalase and bile esculin tests, positive reactions with Christie, Atkins, MunchPetersen (CAMP) and hippurate hydrolysis tests, resistance to bacitracin, and belonging to the Lancefield group B, have presumptively identified S. agalactiae isolates.

\section{Antimicrobial susceptibility patterns}

The in vitro antibiogram results of $S$. agalactiae isolates $(n=14)$ against 15 widely used antimicrobials of 7 chemotherapeutic classes are included in Table 1. S. agalactiae showed high susceptibility to imipenem and ciprofloxacin (100\% each), followed by trimethoprim-sulfamethoxazole (71.43\%). However, a full resistance (100\%) was observed towards penicillin G, amoxicillin, cloxacillin, ceftriaxone, cefoperazone, cephalexin, streptomycin, clindamycin, tetracycline, and erythromycin. All S. agalactiae isolates were categorized as MDR, and their multiple antibiotic resistance (MAR) indices were far greater than $0.2(0.71-$ $0.86)$. 


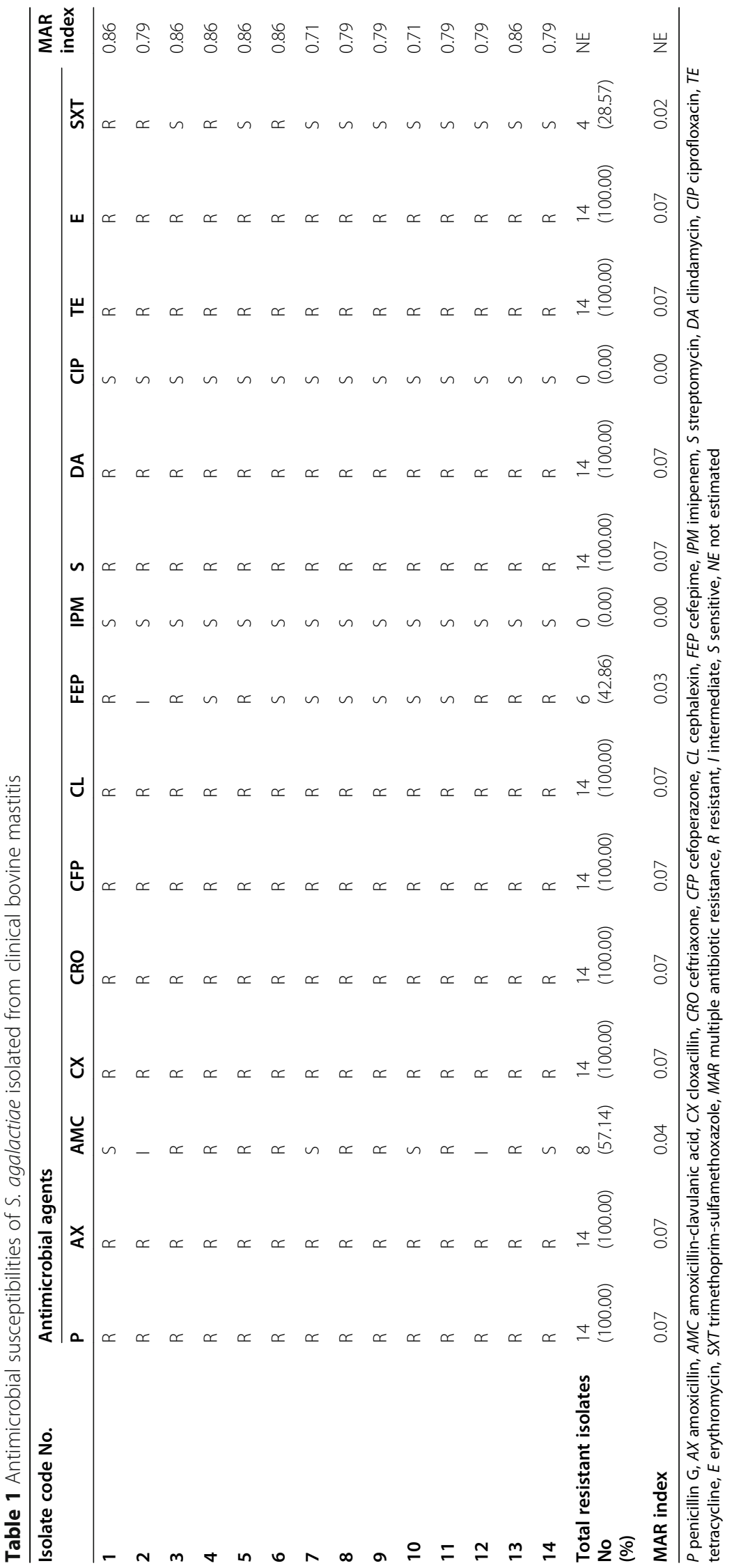


Molecular identification and virulence determinants of $S$. agalactiae isolates

$S$. agalactiae isolates were confirmed by polymerase chain reaction (PCR)-based amplification of the tuf gene (196-bp amplicons) followed by DNA sequencing. Direct sequencing of the amplified products revealed 180-bp sequences between the forward and reverse primers. These sequences were highly conserved among Streptococci species and presented high nucleotide sequence identities ranged from 98.89-99.44\% with the previously deposited sequences of $S$. agalactiae strains in the GenBank database. Further, the $c f b$ gene confirmed $S$. agalactiae isolates at the species level (153-bp amplicons). $S$. agalactiae isolates were tested by a semi-quantitative reverse transcriptase PCR for the expression of a panel of genes potentially involved in virulence along with the gyrA housekeeping gene as an internal control. All isolates were positive for $h y l, c y l E, s c p B$, and $l m b$ mRNA expressions, resulting in expected DNA fragments of 950, 248, 255, and 397-bp, respectively, whereas the sip and rip genes were not expressed in any isolate. The expression levels (as relative units) of hyl (1.10-1.37), cylE (0.97-1.13), $s c p B$ (1.04-1.44), and $\operatorname{lmb}(1.42-1.81)$ virulence genes are demonstrated in Table 2.

\section{Antimicrobial activities of cinnamon oil and AgNPs against planktonic S. agalactiae}

The antimicrobial potentials of cinnamon oil or AgNPs against virulent and MDR S. agalactiae were assessed by evaluating the inhibition zones' diameters and the minimum inhibitory concentration (MIC) values (Table 3). The essential oil diluent, dimethyl sulfoxide (DMSO), was inactive against all investigated isolates. Cinnamon oil exhibited a marked inhibitory effect against $S$. agalactiae with inhibition zones diameters up to $40 \mathrm{~mm}$. This efficacy was reflected with the low recorded MICs ( $\leq$ $0.063 \mu \mathrm{g} / \mathrm{mL}$ ). However, AgNPs demonstrated moderate antimicrobial action against analyzed isolates with inhibition zones' diameters and MIC values up to $31 \mathrm{~mm}$ and $16 \mu \mathrm{g} / \mathrm{mL}$, respectively. For all screened isolates, cinnamon oil and AgNPs showed 2-fold higher minimum bactericidal concentration $(\mathrm{MBC})$ values than their recorded MICs, indicating their bactericidal effect. Furthermore, the MIC50 and MIC90 values of cinnamon oil (0.016 and $0.008 \mu \mathrm{g} / \mathrm{mL}$, respectively) and AgNPs (8 and $16 \mu \mathrm{g} / \mathrm{mL}$, respectively) against $S$. agalactiae isolates were recorded.

As depicted in Table 3, the results of fractional inhibitory concentration index ( $\mathrm{FIC})$ of the checkerboard assay showed a synergistic interaction between cinnamon oil and AgNPs against all S. agalactiae isolates. It is noteworthy that when the two compounds were combined, the MICs of cinnamon oil and AgNPs significantly $(P<0.001)$ decreased 4 to 512 fold and 32 to 128 fold, respectively, indicating that the activity of the combined antimicrobial agents against planktonic S. agalactiae isolates was higher than the sum of their independent activity.

Table 2 Antimicrobial resistance patterns, biofilm forming ability and virulence genes expression levels in S. agalactiae isolated from clinical bovine mastitis

\begin{tabular}{|c|c|c|c|c|c|c|c|c|c|c|}
\hline \multirow{2}{*}{$\begin{array}{l}\text { Isolate } \\
\text { No }\end{array}$} & \multirow[t]{2}{*}{ Antimicrobial resistance pattern } & \multicolumn{2}{|c|}{ Biofilm formation } & \multicolumn{6}{|c|}{ Virulence genes relative expression $^{\mathbf{b}}$} & \multirow{2}{*}{$\begin{array}{l}\text { Accession } \\
\text { No. }\end{array}$} \\
\hline & & ${\mathrm{OD} 570^{\mathrm{a}}}$ & Degree & hyl & cylE & $\operatorname{sip}$ & $s c p B$ & rip & $\operatorname{lmb}$ & \\
\hline 1 & $P, A X, C X, C R O, C L, F E P, S, D A, T E, E, C F P$ & 0.498 & Weak & 1.16 & 1.09 & - & 1.20 & - & 1.50 & MW133069 \\
\hline 2 & $P, A X, C X, C R O, C L, F E P, S, D A, T E, E, A M C$ & 0.492 & Weak & 1.15 & 1.12 & - & 1.21 & - & 1.53 & MW133070 \\
\hline 3 & $P, A X, C X, C R O, C L, F E P, S, D A, T E, E, A M C$ & 1.121 & Strong & 1.10 & 1.04 & - & 1.14 & - & 1.42 & MW133071 \\
\hline 4 & $P, A X, C X, C R O, C L, F E P, S, D A, T E, E, C F P, S X T, A M C$ & 0.514 & Weak & 1.14 & 1.07 & - & 1.16 & - & 1.43 & MW133072 \\
\hline 5 & $P, A X, C X, C R O, C L, F E P, S, D A, T E, E, C F P, S X T$ & 0.508 & Weak & 1.13 & 1.04 & - & 1.15 & - & 1.45 & MW133073 \\
\hline 6 & $P, A X, C X, C R O, C L, F E P, S, D A, T E, E, A M C$ & 0.484 & Weak & 1.16 & 0.97 & - & 1.15 & - & 1.46 & MW133074 \\
\hline 7 & $P, A X, C X, C R O, C L, F E P, S, D A, T E, E, A M C$ & 0.812 & Moderate & 1.13 & 1.05 & - & 1.23 & - & 1.47 & MW133075 \\
\hline 8 & $P, A X, C X, C R O, C L, F E P, S, D A, T E, E, C F P$ & 0.494 & Weak & 1.37 & 1.05 & - & 1.44 & - & 1.81 & MW133076 \\
\hline 9 & $P, A X, C X, C R O, C L, F E P, S, D A, T E, E, A M C$ & 0.492 & Weak & 1.14 & 1.13 & - & 1.22 & - & 1.53 & MW133077 \\
\hline 10 & $P, A X, C X, C R O, C L, F E P, S, D A, T E, E, A M C$ & 1.118 & Strong & 1.11 & 1.04 & - & 1.04 & - & 1.43 & MW133078 \\
\hline 11 & $P, A X, C X, C R O, C L, F E P, S, D A, T E, E, C F P, S X T, A M C$ & 0.434 & Weak & 1.14 & 1.07 & - & 1.14 & - & 1.43 & MW133079 \\
\hline 12 & $P, A X, C X, C R O, C L, F E P, S, D A, T E, E, C F P, S X T$ & 0.528 & Weak & 1.13 & 1.04 & - & 1.16 & - & 1.46 & MW133080 \\
\hline 13 & $P, A X, C X, C R O, C L, F E P, S, D A, T E, E$ & 0.470 & Weak & 1.14 & 1.03 & - & 1.06 & - & 1.45 & MW133081 \\
\hline 14 & $P, A X, C X, C R O, C L, F E P, S, D A, T E, E$ & 0.820 & Moderate & 1.14 & 1.06 & - & 1.15 & - & 1.48 & MW133082 \\
\hline
\end{tabular}

$P$ penicillin $G, A X$ amoxicillin, $C X$ cloxacillin, $C R O$ ceftriaxone, $C L$ cephalexin, FEP cefepime, $S$ streptomycin, $D A$ clindamycin, $T E$ tetracycline, $E$ erythromycin, $C F P$ cefoperazone, AMC amoxicillin-clavulanic acid, SXT trimethoprim-sulfamethoxazole

${ }^{\text {a }}$ The optical density (OD) was measured at $570 \mathrm{~nm}$ using the ELISA reader (stat fax 2100, USA)

${ }^{b}$ The expression level of each virulence gene was calculated as the ratio of intensity of the target gene to the internal control gene ( $g y r A$ ) 
Table 3 In vitro antibacterial activities of cinnamon oil, silver nanoparticles and their combination against S. agalactiae isolated from clinical bovine mastitis

\begin{tabular}{|c|c|c|c|c|c|c|c|c|c|c|c|}
\hline \multirow{3}{*}{$\begin{array}{l}\text { Isolate } \\
\text { No. }\end{array}$} & \multicolumn{6}{|c|}{ Zone diameters for the agar well diffusion method $(\mathrm{mm})^{*}$} & \multicolumn{3}{|c|}{$\operatorname{MIC}(\mu \mathrm{g} / \mathrm{mL})^{* *}$} & \multirow[t]{3}{*}{$\Sigma \mathrm{FIC}$} & \multirow{3}{*}{$\begin{array}{l}\text { Interactive } \\
\text { category }\end{array}$} \\
\hline & \multicolumn{3}{|c|}{ Cinnamon oil (\%) } & \multicolumn{3}{|c|}{ Silver nanoparticles (\%) } & \multirow{2}{*}{$\begin{array}{l}\text { Cinnamon } \\
\text { oil }\end{array}$} & \multirow{2}{*}{$\begin{array}{l}\text { Silver } \\
\text { nanoparticles }\end{array}$} & \multirow{2}{*}{$\begin{array}{l}\text { Cinnamon oil/ } \\
\text { Silver nanoparticles }\end{array}$} & & \\
\hline & 100 & 50 & 25 & 100 & 50 & 25 & & & & & \\
\hline 1 & 38 & 29 & 20 & 31 & 24 & 18 & 0.063 & 8 & $0.00012 / 0.125$ & 0.02 & Synergistic \\
\hline 2 & 40 & 31 & 23 & 29 & 22 & 17 & 0.004 & 8 & $0.0005 / 0.250$ & 0.16 & Synergistic \\
\hline 3 & 40 & 30 & 22 & 30 & 23 & 16 & 0.016 & 8 & $0.0005 / 0.250$ & 0.06 & Synergistic \\
\hline 4 & 39 & 28 & 19 & 28 & 25 & 19 & 0.016 & 16 & $0.002 / 0.125$ & 0.13 & Synergistic \\
\hline 5 & 36 & 27 & 18 & 30 & 21 & 17 & 0.008 & 16 & $0.002 / 0.125$ & 0.26 & Synergistic \\
\hline 6 & 36 & 26 & 18 & 28 & 21 & 15 & 0.031 & 16 & $0.0005 / 0.250$ & 0.03 & Synergistic \\
\hline 7 & 40 & 33 & 21 & 29 & 23 & 18 & 0.063 & 8 & $0.0005 / 0.250$ & 0.04 & Synergistic \\
\hline 8 & 36 & 28 & 21 & 30 & 21 & 17 & 0.016 & 8 & $0.002 / 0.125$ & 0.14 & Synergistic \\
\hline 9 & 40 & 32 & 23 & 30 & 22 & 16 & 0.004 & 8 & $0.0005 / 0.250$ & 0.16 & Synergistic \\
\hline 10 & 40 & 30 & 22 & 28 & 22 & 16 & 0.063 & 16 & $0.00012 / 0.125$ & 0.01 & Synergistic \\
\hline 11 & 39 & 30 & 21 & 31 & 23 & 18 & 0.016 & 8 & $0.002 / 0.125$ & 0.02 & Synergistic \\
\hline 12 & 36 & 28 & 19 & 28 & 25 & 19 & 0.016 & 16 & $0.0005 / 0.250$ & 0.05 & Synergistic \\
\hline 13 & 36 & 26 & 18 & 29 & 22 & 17 & 0.031 & 8 & $0.0005 / 0.250$ & 0.05 & Synergistic \\
\hline 14 & 40 & 34 & 23 & 27 & 20 & 15 & 0.008 & 16 & $0.002 / 0.125$ & 0.3 & Synergistic \\
\hline $\begin{array}{l}\text { Mean } \pm \\
\text { SE }\end{array}$ & $\begin{array}{l}38.29 \pm \\
0.50^{\mathbf{a}}\end{array}$ & $\begin{array}{l}29.43 \pm \\
0.66^{\mathbf{b}}\end{array}$ & $\begin{array}{l}20.57 \pm \\
0.51^{c}\end{array}$ & $\begin{array}{l}29.14 \pm \\
0.33^{\mathbf{a}}\end{array}$ & $\begin{array}{l}22.43 \pm \\
0.40^{\mathbf{b}}\end{array}$ & $\begin{array}{l}17.00 \pm \\
0.35^{c}\end{array}$ & $\begin{array}{l}0.01 \pm \\
0.01^{\mathbf{a}}\end{array}$ & $\begin{array}{l}11.43 \pm \\
1.10^{\mathbf{a}}\end{array}$ & $\begin{array}{l}0.0010 \pm 0.0002^{\mathbf{b}} / \\
0.19 \pm 0.02^{\mathbf{b}}\end{array}$ & - & - \\
\hline
\end{tabular}

MIC minimum inhibitory concentration, $\Sigma F I C$ fractional inhibitory concentration index; SE, standard error

* Means \pm standard errors of the inhibition zones` diameters for different concentrations (25, 50 and $100 \%)$ of cinnamon oil or silver nanoparticles carrying different superscripts are highly significant $(P<0.0001)$

** Means \pm standard errors of the MIC values of cinnamon oil or silver nanoparticles (serial dilutions were done for each antibacterial agent starting from $1024 \mu \mathrm{g} /$ $\mathrm{mL}$ and downwards) and their combination carrying different superscripts are highly significant $(P<0.0001)$

To assess the killing kinetics of MIC levels of cinnamon oil, AgNPs, and their combination against MDR $S$. agalactiae isolates, the viability of the cells was evaluated in a multi-time point assay (Fig. 1). The MIC level of cinnamon oil significantly reduced $(P<0.05)$ the planktonic cell population by approximately $1-3 \log _{10}$ colony- forming units $(\mathrm{CFU}) / \mathrm{mL}$ after $10 \mathrm{~h}$ of incubation, while no CFU was detected after $12 \mathrm{~h}$ of incubation. Also, AgNPs significantly decreased $(P<0.05)$ the number of viable cells but with lower efficacy ( $2 \log _{10}$ after $24 \mathrm{~h}$ of incubation). However, exposure of the bacteria to cinnamon oil AgNPs combination resulted in 100\% inhibition

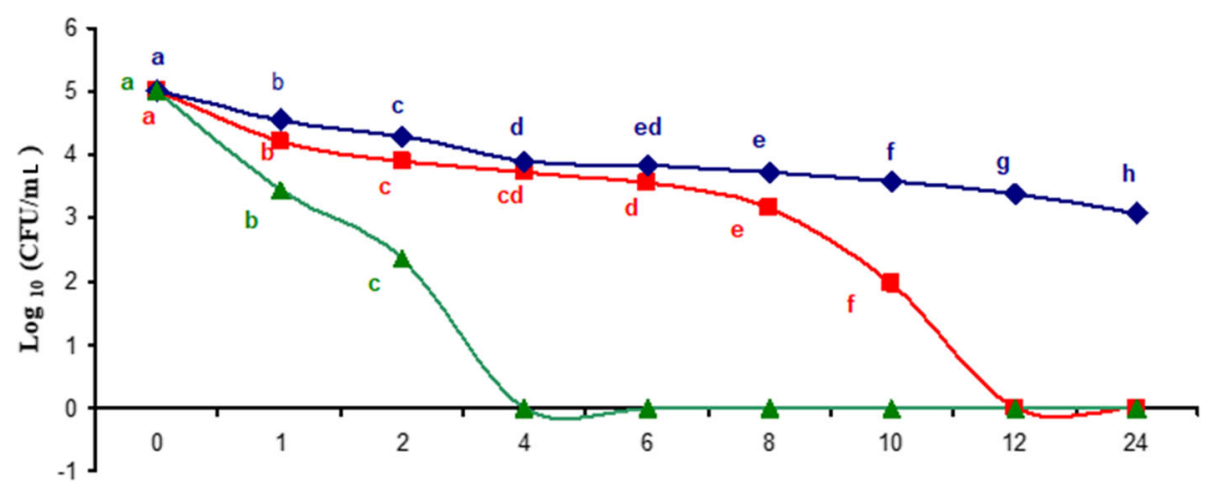

Time (h)

Cinnamon oil $\neg-$ Silver nanoparticles $\neg-$ Cinnamon oil+ Silver nanoparticles

Fig. 1 Killing kinetics of the MIC levels of cinnamon oil, silver nanoparticles, and their combination on the viability of S. agalactiae isolates (timekill curve). Bacterial survival was reported at $0,1,2,4,6,8,10,12$, and $24 \mathrm{~h}$ incubation time points by the colony forming unit (CFU) assay. The data are expressed as the means \pm SE of three separate experiments, each containing three replicates 
of bacterial cells within $4 \mathrm{~h}$, demonstrating that AgNPs enhanced the antimicrobial effect of cinnamon oil.

The biofilm formation ability of $S$. agalactiae isolates Assaying the biofilm formation by 14 MDR $S$. agalactiae isolates using the crystal violet staining method resulted in a range of absorbance values from 0.484 to 1.121 . All tested S. agalactiae isolates turned out to be biofilm producers; among them, 2 (14.29\%), 2 (14.29\%), and 10 (71.43\%) isolates were categorized as strong, moderate, and weak biofilm producers, respectively, all were resistant to at least 10 antimicrobial agents (Table 2).

\section{Antibiofilm activities of cinnamon oil and silver nanoparticles}

The effects of cinnamon oil, AgNPs, and their combination on preexisting biofilms produced by $S$. agalactiae are shown in Figs. 2 and 3. The antibiofilm activities seem to be concentration- dependent (Fig. 2). Our results revealed a good antibiofilm activity (>50\% inhibition of biofilm formation) of cinnamon oil against the preformed biofilms of $S$. agalactiae isolates with the most repeated minimum biofilm inhibitory concentrations $_{50}\left(\mathrm{MBIC}_{50}\right)$ of $4 \mu \mathrm{g} / \mathrm{mL}$ (Fig. 3A). However, the antibiofilm activity of AgNPs was lower than cinnamon oil with the most repeated $\mathrm{MBIC}_{50}$ of $64 \mu \mathrm{g} / \mathrm{mL}$ (Fig. $3 a)$. The results were compared with the untreated (positive controls) $S$. agalactiae biofilm producers as well as the negative controls (non-biofilm producers). Interestingly, AgNPs cinnamon oil combination has a moderate ability to remove the preformed biofilms by $S$. agalactiae isolates with $\mathrm{MBIC}_{50}$ range of $1 / 2-32 / 64 \mu \mathrm{g} / \mathrm{mL}$ (Fig. $3 \mathrm{~b})$. The $\Sigma \mathrm{FIC}$ of their $\mathrm{MBIC}_{50}$ values revealed an interactive category of addition in 4 isolates only, other isolates $(n=10)$ showed an antagonistic interaction.

\section{Scanning electron microscopy (SEM) observations}

The impact of cinnamon oil, AgNPs, and their combination on the biofilm integrity of strong biofilm producer $S$. agalactiae isolates reported in this study $(n=2)$ was investigated via SEM. The results showed that the biofilms of control untreated strong biofilm producer isolates were compact and integral. When the $\mathrm{MBIC}_{50}$ of cinnamon oil, AgNPs, and their combination were added, the biofilms were damaged to variable degrees compared to the control non-treated isolates (Additional File 1). When the cultures were exposed to cinnamon oil, the biofilms were seriously damaged. Meanwhile, the biofilms of AgNPs treated isolates showed only slight surface crack, and it was possible to observe the biofilms with apparently fewer cell layers. The biofilms of the AgNPs cinnamon oil combinationtreated isolates were hardly damaged to a lower extent than cinnamon oil-treated ones indicating that cinnamon oil alone exhibited more potent inhibitory activity against biofilm formation of $S$. agalactiae than AgNPs either alone or in combination.

\section{Modulation of biofilm-associated genes}

To further confirm the inhibitory effects of the $\mathrm{MBIC}_{50}$ of cinnamon oil, AgNPs, and their combination on the preexisting biofilms of strong biofilm-producing $S$. agalactiae isolates reported here $(n=2)$, the transcript levels of biofilm-associated genes; pilA and pilB, and their regulator $(\operatorname{rog} B)$ were determined by reverse transcriptase quantitative polymerase chain reaction (RT-qPCR). Data analysis indicated that $S$. agalactiae isolates showed low transcript levels of pili biosynthesis genes (pilA and $p i l B$ ) in response to the down-regulation of $\operatorname{rog} B$ gene in all treatments when compared to the untreated biofilmproducing isolates. The lowest mRNA expression levels of $\operatorname{rog} B(0.372 \pm 0.016$ fold), pilA ( $0.475 \pm 0.031$ fold), and pilB $(0.613 \pm 0.046$ fold) genes were ubiquitously detected in the isolates exposed to the $\mathrm{MBIC}_{50}$ of

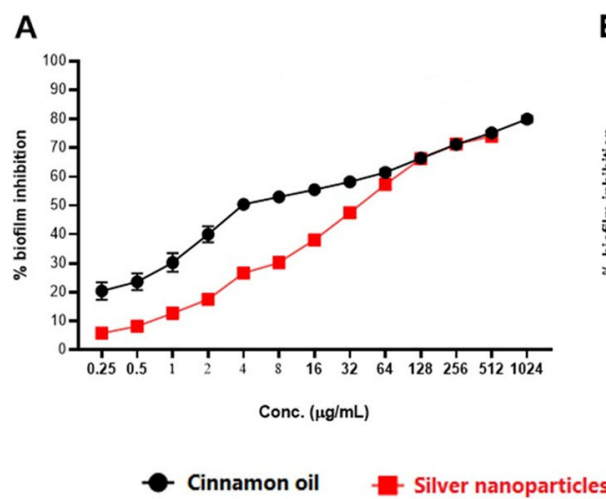

B

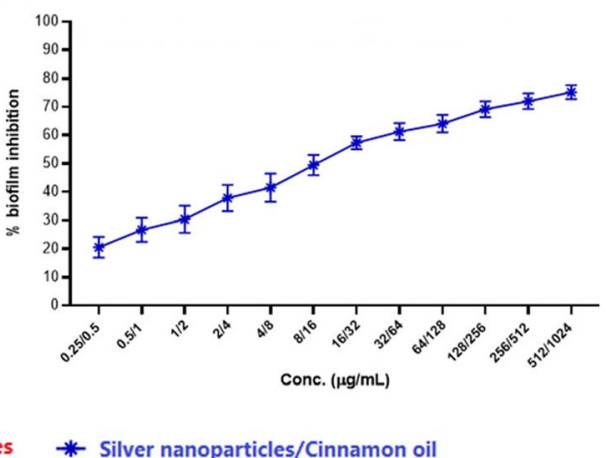

Fig. 2 Increased percentages of biofilm inhibition (X-axis) correspond to a serial concentration (Y-axis) of cinnamon oil, silver nanoparticles (a), and both substances (b). Each data point refers to the average of biofilm inhibition $\%$ at the respective concentration, and the error bar refers to the standard error mean 

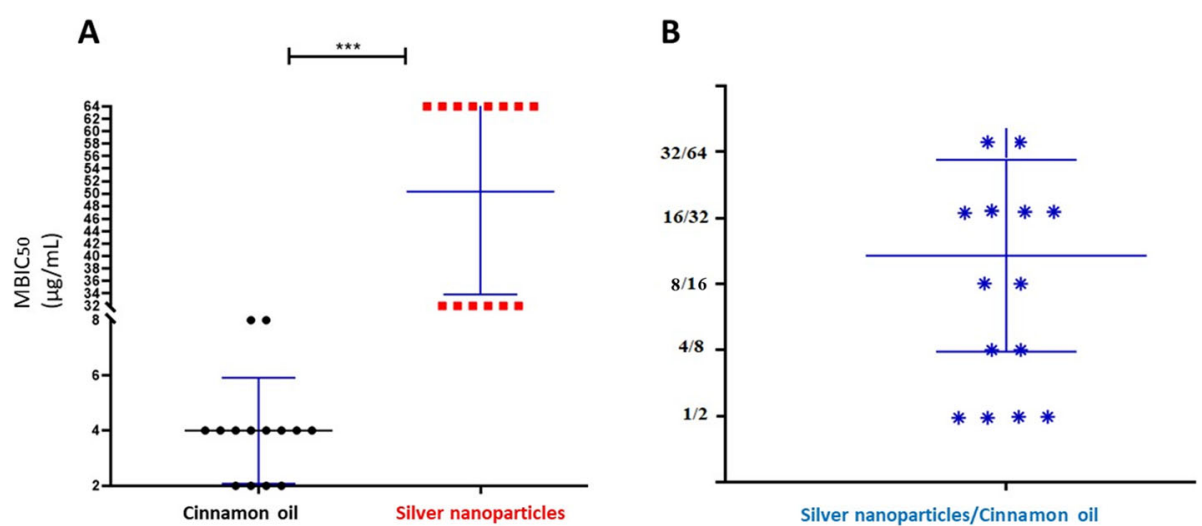

Fig. 3 Effects of cinnamon oil, silver nanoparticles (a), and their combination (b) on the biofilm formation of S. agalactiae. For each substance, the number of isolates exhibiting certain $\mathrm{MBIC}_{50}$ is shown + /- standard error mean. Stars indicate a significant difference among the $M B C_{50}$ of cinnamon oil and silver nanoparticles

$$
\begin{aligned}
& \mathrm{r}(\text { pil } A-\operatorname{rog} B)=0.974 * * \\
& \mathrm{r}(\text { pil } B-\operatorname{rog} B)=0.884 * *
\end{aligned}
$$

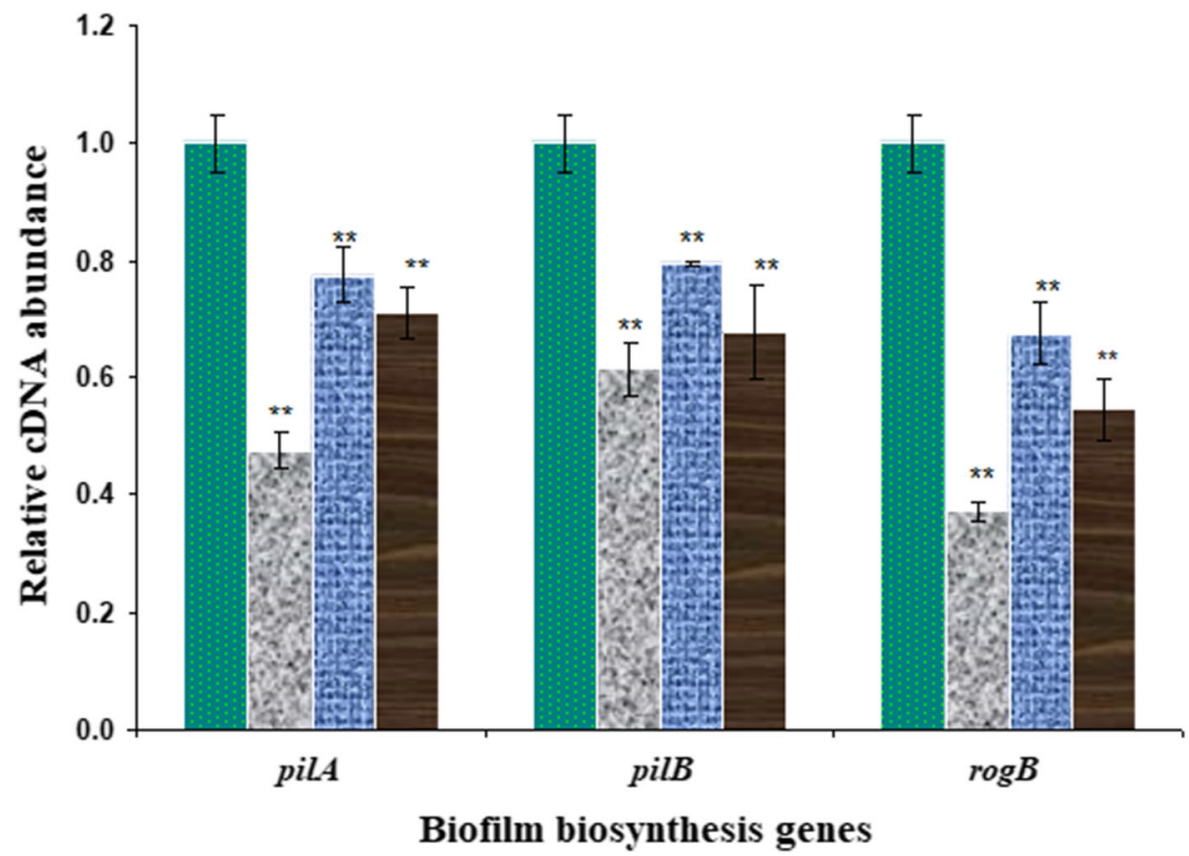

Fig. 4 Comparative measurement of the transcription (cDNA abundance) of biofilm associated genes (pilA and pilB) and their regulator (rogB) in strong biofilm producing S. agalactia isolates (codes No. 3 and 10; Table 2) after treatment with $\mathrm{MBIC}_{50}$ values of cinnamon oil $(2,4 \mu \mathrm{g} / \mathrm{mL}$ ), silver nanoparticles $(32,64 \mu \mathrm{g} / \mathrm{mL})$ and their combination $(1 / 2,8 / 16 \mu \mathrm{g} / \mathrm{mL})$, respectively. The data are presented as fold changes in gene expressions normalized to an endogenous housekeeping gene ( $g y r A)$ and relative to the untreated control isolate, which was assigned a value of 1.Error bars indicate standard deviations. Double asterisks $\left(^{* *}\right)$ represent the means significantly different from control untreated isolate $(P<0.05)$. Pearson's correlation indicates the positive correlations of rogB transcript levels and biofilm biosynthesis genes at $r \geq 0.3$ 
cinnamon oil alone followed by cinnamon oil combined with AgNPs $(0.545 \pm 0.052,0.708 \pm 0 ., 044$ and $0.676 \pm$ 0.081 folds for $\operatorname{rog} B$, pilA, and pilB genes, respectively). Meanwhile, the entire set of the tested genes decreased to lower extents $(0.673 \pm 0.053, \quad 0.775 \pm 0.048$, and $0.795 \pm 0.005$ folds for $\operatorname{rog} B$, pilA, and pilB genes, respectively) after exposure to the $\mathrm{MBIC}_{50}$ of AgNPs. Statistical analysis revealed significant $(P<0.05)$ positive correlations $(r \geq 0.3)$ between the transcript levels of $\operatorname{rog} B$ regulatory gene and pili biosynthesis genes for all tested isolates (Fig. 4).

\section{Discussion}

Mastitis is a common disease in dairy animals worldwide. It causes morbidity in highly productive cows and financial losses in the dairy industry. Contagious pathogens as S. agalactiae [10] and S. aureus [19] are important etiological bacterial agents causing mastitis in dairy cows with an increasing tendency worldwide. Unconventional therapies as Ethnoveterinary medicine have been given more attention since bacterial pathogens causing mastitis are becoming progressively resistant to conventional antimicrobial therapy [20]. We inferred that new clinical mastitis treatment strategies, particularly against contagious pathogens, should be implemented in Egyptian dairy herds. Therefore, the antimicrobial and antibiofilm activities of cinnamon oil, AgNPs, and their combination were investigated against MDR S. agalactiae isolates.

In this study, the occurrence of $S$. agalactiae was relatively low $(9.59 \%)$, which was similar to the result reported by Shome et al. [21] (8.1\%), lower than that reported in another study in Egypt [8] (31.6\%), but higher than the result of Gangwal and coauthors [22] (2\%). The predominance of microorganisms varies according to breed, handling animals practices, hygienic conditions during milking, geographical areas, and climatic conditions.

The expression of virulence genes in S. agalactiae isolated from clinical cases of bovine mastitis could explain a probable implication of these genes with the pathogenesis of mammary infections. In this investigation, the expression of virulence genes required for colonization and adherence $(l m b, s c p B)$ as well as invasion ( $c y l E$ and $h y l)$, was reported in all tested $S$. agalactiae isolates by a semi-quantitative reverse transcriptase PCR, suggesting that these isolates state a greater probability of causing the disease. A perusal search of the literature revealed scarce reports available on the expression of the virulence determinants of $S$. agalactiae accused of bovine mastitis [23], however, their existence was numerously investigated. In previous reports, the existence of $s c p B$ and $\operatorname{lmb}$ genes was reported in $S$. agalactiae derived from mastitic cattle in the Middle East [24]. CylE gene was found in bovine S. agalactiae in Poland [10], while the hyl gene existed in bovine but not in human invasive S. agalactiae isolates in New York [25].

Antimicrobial resistance among streptococcal mastitis isolates has become an increasingly prevalent problem in Egypt. In the current study, S. agalactiae exhibited complete resistance to 10 out of 15 tested antimicrobial drugs. Likewise, high levels of resistance to clindamycin $(80 \%)$, erythromycin and tetracycline (68\% each), amoxicillin (60\%), and penicillin (52\%) were previously reported in a recent study in Egypt [7]. In another study in China [14], 88.9\% of streptococci isolates recovered from mastitic cows were MDR. It is widely assumed that amoxicillin and cephalexin exhibited the best activity against streptococcal mastitis [26]. However, the emergence of resistance to both antibiotics was previously documented $[9,14]$, which is consistent with our findings. Hence, this study suggests the need for judicious use of antimicrobial agents in veterinary medicine to avoid the increase and spreading of antimicrobial resistance in animals and humans. Moreover, the search for new and appropriate effective antimicrobial compounds is urgently recommended particularly, against contagious mastitis pathogens as S. agalactiae.

In this study, cinnamon oil showed strong inhibitory activity against $S$. agalactiae isolates (inhibition zone diameters $\leq 40 \mathrm{~mm}$ and MIC values $\leq 0.063 \mu \mathrm{g} / \mathrm{mL}$ ). However, in a previous study [27], it was reported that transcinnamaldehyde demonstrated high bactericidal activity against planktonic cells of $S$. agalactiae causing bovine mastitis with a MIC value of $0.5 \mathrm{mg} / \mathrm{mL}$. The bioactive components of the essential oils act on cell membrane integrity by altering membrane permeability, resulting in leakage of electrolytes and loss of vital intracellular contents. Additionally, they inhibit the adenosine triphosphate generation and related enzymes. Those can detrimentally influence cell metabolism and lead to cell death [28]. Metallic nanoparticles have generally been studied because of their broad-spectrum antimicrobial activity, even at low concentrations [29]. Moreover, the combination of nanoparticles with various compounds has displayed potent antimicrobial effects on different microbial pathogens, particularly those displaying resistance to conventional antibiotics [30].

Here, AgNPs showed reasonable antimicrobial activity against the tested S. agalactiae isolates. Moreover, synergistic antimicrobial interaction of cinnamon oil with AgNPs against $S$. agalactiae was reported. A recent study demonstrated that nanoparticles functionalized with essential oils have significant antimicrobial activity against MDR pathogens [30].

Accordingly, the synergistic or additive effect of cinnamaldehyde with chemically synthesized AgNPs against Gram-positive and Gram-negative bacteria has been 
previously reported [31]. In this context, using essential oils combined with nanoparticles may employ a synergistic antimicrobial action, leading to the development of a new approach for treatments.

Time-kill kinetic study indicated that cinnamon oil AgNPs combination exhibited bactericidal activity against S. agalactiae isolates as $100 \%$ inhibition of planktonic cells was achieved over the first $4 \mathrm{~h}$ of exposure compared to the control untreated isolates. Accordingly, AgNPs activity may be strongly enhanced when utilized in the presence of cinnamaldehyde as previously documented [31].

Current antimicrobials have a restricted effect on biofilms. Adhered bacteria in these communities have distinct physiological features compared to free planktonic cells. These features can protect the bacteria against host immunity as well as the antimicrobial drugs, resulting in persistent infections and difficult treatment [32]. In this study, cinnamon oil exhibited a higher antimicrobial action against the preexistent biofilms of $S$. agalactiae $\left(\mathrm{MBIC}_{50} 4 \mu \mathrm{g} / \mathrm{mL}\right.$ ) than that observed by AgNPs (most repeated $\mathrm{MBIC}_{50}$ is $64 \mu \mathrm{g} / \mathrm{mL}$ ). However, AgNPs cinnamon oil combination moderately increased the antibiofilm efficacy of AgNPs with an $\mathrm{MBIC}_{50}$ range of 1/2-32/ $64 \mu \mathrm{g} / \mathrm{mL}$. To our knowledge, there were no published data regarding the use of cinnamon oil or AgNPs as alternative antimicrobials against biofilm production by $S$. agalactiae isolated from clinical mastitis. Also, the current study appears to be the first to explore the antimicrobial potentials of cinnamon oil combined with AgNPs toward the planktonic or biofilm-producing $S$. agalactiae field isolates.

The potential explanation of our results could be retrieved from the literature. As documented previously, the AgNPs have antibacterial activities even at low concentrations. Their combination with essential oils allows the use of lowered concentrations of both agents against the planktonic cells in an effective way [31]. However, another study demonstrated that AgNPs combined with natural products may have antibiofilm activity when used at higher concentrations as adhered bacteria have different physiological features compared to the freefloating cells [33].

To investigate the influence of antimicrobial agents understudy on the biofilm integrity of S. agalactiae, an SEM experiment was applied. The results revealed that $S$. agalactiae biofilms were seriously damaged after exposure to $\mathrm{MBIC}_{50}$ of cinnamon oil than that was observed in AgNPs cinnamon oil combination. Meanwhile, only a slight surface crack was detected in the biofilm after AgNPs treatment. Similarly, only simple surface fissures were observed in the preformed biofilm of an MDR E. coli strain isolated from a mastitic dairy cow when examined by SEM after treatment with AgNPs
[34], while no available data regarding the investigation of the antibiofilm activities of cinnamon oil alone or combined with AgNPs against S. agalactiae was recorded using SEM.

Another novel finding in this study was the remarkable down-regulation of pili biosynthesis genes responsible for biofilm development after treatment with cinnamon oil followed by AgNPs- cinnamon oil combination. Meanwhile, the AgNPs cinnamon oil combination demonstrated a lower efficacy. These findings provide novel insights into the antimicrobial potential of natural herbal products and suggest a promising therapeutic activity against MDR and biofilm-producing bacteria.

Thus, the biofilm components could be potential new targets for new anti-mastitis agents. However, there are no available in vivo studies supporting the hypothesis that biofilm-producing microorganisms contribute to the resistance to antimicrobial agents more than their planktonic counterparts as well as the persistence of intramammary infections on the farm. The knowledge gained from our study could be viewed as an in vitro preliminary validation of natural products for the mitigation of bacterial resistance. However, no way supports the clinical use of these compounds in mastitis treatment without in vivo studies. Further in vivo studies in animal models should be carried out to show (i) a proof of concept of the therapeutic potential of the examined antibacterial agents against streptococcal mastitis, (ii) their anticipated effects on the udder tissue, and (iii) food safety implications, including meat and milk withhold times.

\section{Conclusion}

Our findings provide a comprehensive overview of the bactericidal activity of cinnamon oil and its synergistic effect with AgNPs against planktonic cells of $S$. agalactiae recovered from clinical mastitis. Moreover, this work is the first to demonstrate the antibiofilm potency of cinnamon oil against preexistent biofilms of $S$. agalactiae isolates. These results exhibited the potential of natural products as a promising alternative for improving future dosing strategies to treat $S$. agalactiae infections in bovine mastitis.

\section{Methods}

\section{Sample collection and ethical approval}

Clinical samples were obtained from eight dairy herds in different Governorates in Egypt, during the period from September 2016 to March 2018. Quarter milk samples were aseptically collected from 200 Holstein Friesian cows (Frisona $\mathrm{GmbH}$, Germany) with clinical mastitis (each quarter represented an animal) in compliance with the recommendations of the National Mastitis Council [35]. In brief, the teat end was thoroughly disinfected 
with ethanol-drenched cotton swabs (70\%). The first three to four streams of milk were discarded. Individual quarter milk samples were then collected aseptically in sterile plastic screw-capped tubes. New latex gloves were used for each sampling procedure from each cow. Milk samples were kept at $4{ }^{\circ} \mathrm{C}$ in an insulated icebox and transported to the Bacteriology Laboratory, Faculty of Veterinary Medicine, Zagazig University, Egypt, for further investigations. Criteria describing clinical mastitis were low milk yield, abnormal milk secretion (watery, bloody, or purulent), presence of flakes or clots, and the cardinal signs of inflammation on infected mammary quarters. Recruitment of dairy cows into this work was done in consultation with veterinarians, and sampling was performed after the permission of dairy farms owners. The study was approved by the committee of Animal Welfare and Research Ethics, Faculty of Veterinary Medicine, Zagazig University, Egypt.

\section{Bacteriological analyses}

Bacteriological examination of milk samples was performed according to the procedures employed previously [36]. Briefly, $1 \mathrm{~mL}$ of each thoroughly mixed milk sample was transferred to $10 \mathrm{~mL}$ of brain heart infusion (BHI; Oxoid, Hampshire, England, UK) broth then incubated at $37{ }^{\circ} \mathrm{C}$ for $18 \mathrm{~h}$ to resuscitate the microorganisms. A loopful of the pre-enriched milk sample was plated onto Edward's agar medium (Oxoid, Hampshire, England, UK) and incubated at $37^{\circ} \mathrm{C}$ for $24 \mathrm{~h}$. A single, wellisolated colony was subcultured onto a blood agar base (Oxoid, Hampshire, England, UK) enriched with 7\% sterile defibrinated sheep blood and incubated aerobically at $37^{\circ} \mathrm{C}$ for $24-48 \mathrm{~h}$. The plates were examined for their typical growth, morphological features, and hemolytic characteristics. Growth at 10 and $45^{\circ} \mathrm{C}$, at pH 9.6, and in $6.5 \% \mathrm{NaCl}$, in addition to the resistance to the bile salts, were investigated for separating Enterococci from Streptococci species [37]. A battery of biochemical tests, including catalase, sodium hippurate, and esculin hydrolysis, was conducted as per Hardie [38]. A bacitracin sensitivity test was applied for differentiating $S$. pyogenes (sensitive) from other bacitracin-resistant streptococci (S. agalactiae, S. dysagalactiae, and group D nonenterococcus streptococci) [39]. Christie, Atkins, and Munch-Petersen (CAMP) test was applied to distinguish S. agalactiae isolates (CAMP-positive) [40]. Serotyping of streptococci isolates was done using commercial antisera (Oxoid, Hampshire, England, UK) according to the manufacturer's instructions.

\section{Antimicrobial susceptibility testing}

Antimicrobial susceptibility testing of $S$. agalactiae isolates against 15 widely used antimicrobial agents (Oxoid, Hampshire, England, UK) was applied according to the standardized disc diffusion method [41]. The following antimicrobials were tested: Penicillin G (10 U), amoxicillin $(25 \mu \mathrm{g})$, amoxicillin/clavulanic acid $(20 / 10 \mu \mathrm{g})$, cloxacillin $(1 \mu \mathrm{g})$, cefoperazone $(75 \mu \mathrm{g})$, ceftriaxone $(30 \mu \mathrm{g})$, cephalexin $(30 \mu \mathrm{g})$, imipenem $(10 \mu \mathrm{g})$, streptomycin $(10 \mu \mathrm{g})$, ciprofloxacin $(5 \mu \mathrm{g})$, tetracycline $(30 \mu \mathrm{g})$, clindamycin $(2 \mu \mathrm{g})$, erythromycin $(15 \mu \mathrm{g})$ and trimethoprim/sulphamethoxazole $(1.25 / 23.75 \mu \mathrm{g})$. The inhibition zones` diameters were interpreted following the standards available in the Clinical and Laboratory Standards Institute (CLSI) guidelines [42]. The isolates displaying resistance to $\geq 3$ different antimicrobial classes were categorized as MDR. The MAR index for each isolate was calculated as follows: Number of antimicrobials to which the isolate displayed resistance/ Number of antimicrobials to which the isolate had been tested; while the MAR index for each antimicrobial= Total number of resistance scored / (Total number of antimicrobials tested $\times$ Total number of the isolates) [43].

\section{Genotypic characterization of S. agalactiae isolates}

The genomic DNA was extracted using a QIAamp DNA Mini kit (Qiagen $\mathrm{GmbH}$, Germany) following the manufacturer's instructions. Conventional PCR-based amplification of tuf gene [44], followed by DNA sequencing, was applied to confirm the identification of streptococci isolates. PCR products (196 bp) were purified using the QIAquick PCR purification kit (QIAGEN, Valencia, CA, USA) then sequenced by the BigDyeR Terminator v3.1 Cycle Sequencing Kit (Applied Biosystems, USA) in an ABI 3130 automated DNA Sequencer (Applied Biosystems, USA). The tuf gene sequences $(n=14)$ were compared with those previously deposited within the GenBank database using the Basic Local Alignment Search Tool (BLAST) available at the National Center for Biotechnology Information (NCBI, www.ncbi.nlm. nih.gov/BLAST/). The confirmation of $S$. agalactiae isolates was performed by PCR targeted the $c f b$ (CAMP factor) [45] gene using a species-specific primer.

S. agalactiae isolates were then screened for the expression of six virulence genes, namely, hyl (encoding hyaluronate lyase) [25], cylE (encoding $\beta$-hemolysin/cytolysin) [46], sip (encoding surface immunogenic protein) [47], scpB (encoding C5a peptidase) [48], rip (encoding rib surface protein) [49], and $l m b$ (encoding laminin-binding protein) [10], by a semi-quantitative reverse transcriptase PCR. The gyrA gene was used as an internal amplification control [50]. Total RNA extraction was accomplished using a QIAamp RNeasy Mini kit (Qiagen, Germany) according to the supplier's protocol. RNA purity, integrity, and concentration were assayed using Spectrostar NanoDrop ${ }^{\text {Tw }} 2000$ spectrophotometer (Thermo Fisher Scientific, Waltham, USA). Reverse transcription of mRNA into complementary DNA (cDNA) was performed using a High-Capacity RNA-to-cDNA ${ }^{\text {m }}$ 
Kit (Thermo Fisher Scientific, Waltham, USA) according to the manufacturer's instructions. Oligonucleotide primers, product sizes, and annealing temperatures used for all PCR assays are listed in Additional File 2.

All PCR amplification reactions were performed in a PTC- $100^{\text {tw }}$ programmable thermal cycler (MJ Research Inc., Waltham, USA) with a final volume of $25 \mu \mathrm{L}$ of the following reaction mixture: $12.5 \mu \mathrm{L}$ DreamTaq Green PCR Master Mix (2X) (Thermo Fisher Scientific, Waltham, USA), $1 \mu \mathrm{L}$ of each primer (20 pmole), $2 \mu \mathrm{L}$ template DNA and $8.5 \mu \mathrm{L}$ water nuclease-free. The amplified cDNAs were electrophoresed on a $1.5 \%$ agarose gel (Sigma-Aldrich, USA) stained with $0.5 \mu \mathrm{g} / \mathrm{mL}$ ethidium bromide (Sigma-Aldrich, USA). A 100 bp DNA ladder (Fermentas, USA) was used as a molecular weight marker. The gel was visualized using an ultraviolet transilluminator (Spectroline, Westbury, USA) then photographed. The band intensity of each target gene and the gyrA housekeeping gene were quantified using ImageJ software (https://imagej.net/Download). The mRNA expression levels were determined as the ratio of the intensity of the target gene to the internal control gene. Positive (S. agalactiae ATCC 27956) and negative (PCR reaction mixture without DNA) controls were included in all PCR approaches.

\section{Cinnamon oil and silver nanoparticles}

A stock solution of $10 \%$ commercially available cinnamon oil (Sigma Aldrich, Germany) was prepared in tryptic soy broth (TSB; Oxoid, UK) containing 10\% (v/v) DMSO (Sigma Aldrich, Germany). Synthesized AgNPs ranged from 15 to $50 \mathrm{~nm}$ in size and spherical in shape were purchased from Naqaa Co. (Cairo, Egypt). The AgNPs stock solution was prepared as $1 \mu \mathrm{g} / \mathrm{mL}$ by dissolving in an appropriate volume of sterile distilled water.

\section{Antimicrobial activities of cinnamon oil and silver nanoparticles}

The antimicrobial activities of cinnamon oil and AgNPs were assessed against the planktonic MDR S. agalactiae isolates. The agar well diffusion assay was applied as described elsewhere [51], and the isolates with inhibition zones` diameters $\geq 8 \mathrm{~mm}$ were considered susceptible [52]. Minimum inhibitory concentrations (MIC) and MBC of the tested antimicrobial agents were determined using the broth microdilution technique [53]. Moreover, the MIC50 and MIC90 were calculated using an orderly array method [54]. The interactions of the antimicrobial combinations were analyzed by a checkerboard assay [55]. The combination is considered synergistic when the $\Sigma$ FIC is $\leq 0.5$, indifferent when the $\Sigma$ FIC is $>0.5$ to $<$ 2 , and antagonistic when the $\Sigma F I C$ is $\geq 2$ [56].

For time-kill curve analysis, planktonic cells of $S$. agalactiae $\left(1-5 \times 10^{5} \mathrm{CFU} / \mathrm{mL}\right)$ were incubated in TSB containing MIC levels of cinnamon oil, AgNPs and their combination. At determined time points $(0,1,2,4,6,8$, 10 , and $24 \mathrm{~h}$ ), aliquots were aseptically transferred to tryptic soy agar (TSA; Oxoid, UK) plus 5\% sterile defibrinated sheep blood, and the CFU counts were recorded after incubation at $37^{\circ} \mathrm{C}$ for $24 \mathrm{~h}$ [57]. All the assays were applied in triplicate.

\section{Quantitative evaluation of biofilm formation}

Biofilm formation by $S$. agalactiae isolates was induced in triplicate using 96-well sterile flat-bottomed polystyrene microtiter plates (Techno Plastic Products, Switzerland) as documented elsewhere [58]. In brief, an aliquot of $200 \mu \mathrm{L}$ of an initial bacterial suspension $\left(10^{6} \mathrm{CFU} / \mathrm{mL}\right)$ in TSB was added to each well and incubated at $37^{\circ} \mathrm{C}$ for $24 \mathrm{~h}$. The wells were carefully aspirated and washed twice with $200 \mu \mathrm{L}$ of phosphate-buffered saline (PBS, $\mathrm{pH}$ 7.2) to remove the planktonic bacteria then air-dried for $15 \mathrm{~min}$. Biofilms were stained with $0.1 \%(\mathrm{w} / \mathrm{v})$ crystal violet $(100 \mathrm{~mL}$ per well) for 30 min then the wells were washed twice with PBS and airdried. The stained biomass was resuspended in ethanol/acetone solution $(80: 20, v / v)$, and the optical density (OD) was determined using the ELISA reader (stat fax 2100, USA) at $570 \mathrm{~nm}$. Wells originally containing non-inoculated medium as well as a biofilm-producing bacterium ( $S$. agalactiae ATCC 13813) were used as negative and positive controls, respectively. Cut-off optical density value $\left(\mathrm{OD}_{\text {cut }}=\mathrm{OD}_{\mathrm{avg}}\right.$ of negative control $+3 \times$ standard deviation (SD) of ODs of negative control) was used for categorizing $S$. agalactiae isolates based on biofilm-forming capacity as following: No biofilm producer $\left(\mathrm{OD} \leq \mathrm{OD}_{\text {cut }}\right)$, weak biofilm producer $\left(\mathrm{OD}_{\text {cut }}<\mathrm{OD} \leq 2 \times \mathrm{OD}_{\text {cut }}\right)$ moderate biofilm producer $(2 \times$ $\left.\mathrm{OD}_{\text {cut }}<\mathrm{OD} \leq 4 \times \mathrm{OD}_{\text {cut }}\right)$ or strong biofilm producer (OD $>$ $\left.4 \times \mathrm{OD}_{\text {cut }}\right)[59]$.

\section{Antibiofilm assay}

Investigation of cinnamon oil or AgNPs effects on mature biofilms of $S$. agalactiae was carried out by the broth microdilution technique, as stated elsewhere [60] with modification. Briefly, $20 \mu \mathrm{L}$ of cell suspension $\left(10^{6}\right.$ cells $\left./ \mathrm{mL}\right)$ was added to each well having $180 \mu \mathrm{L}$ of TSB. After $24 \mathrm{~h}$ of biofilm maturation, the medium was aspirated off, and each well was washed using sterile PBS. Two hundred microliters $(200 \mu \mathrm{L})$ of TSB containing various concentrations of cinnamon oil (1024$0.25 \mu \mathrm{g} / \mathrm{mL}$ ) or AgNPs $(512-0.25 \mu \mathrm{g} / \mathrm{mL})$ were added, followed by incubation of the plates for $24 \mathrm{~h}$. The percentage of biofilm inhibition was calculated according to the following equation: $1-\left(A_{570}\right.$ of the test isolate/ $A_{570}$ of non-treated control isolate) $\times 100$, where $\mathrm{A}$ is the absorbance value at $570 \mathrm{~nm}$ using the ELISA reader (stat fax 2100, USA). The minimum biofilm inhibitory concentrations (MBIC), the lowest concentrations that exhibited a $50 \%$ or $90 \%$ inhibition of biofilm formation 
$\left(\mathrm{MBIC}_{50}\right.$ and $\mathrm{MBIC}_{90}$, respectively), were then evaluated. Moreover, the interactions of cinnamon oil with AgNPs against biofilm formation were then evaluated by the checkerboard method [56], and fractional MBICs were computed as described before [60]. The negative controls (non-biofilm producers) and the positive controls (wells containing biofilms) were involved. All the procedures were carried out in triplicate.

\section{Scanning electron microscopy}

Streptococcus agalactiae strong biofilm producers (code Nos. 3 and 10 in Table 2) reported in the current study were treated for $5 \mathrm{~h}$ with the $\mathrm{MBIC}_{50}$ of cinnamon oil $(2,4 \mu \mathrm{g} / \mathrm{mL}), \operatorname{AgNPs}(32,64 \mu \mathrm{g} / \mathrm{mL})$ and their combination $(1 / 2,8 / 16 \mu \mathrm{g} / \mathrm{mL})$, respectively. The isolates were fixed using $2.5 \%$ glutaraldehyde in $0.1 \mathrm{M}$ sodium cacodylate buffer (Ladd Research Industries, USA) at $\mathrm{pH} 7.2$ for $2 \mathrm{~h}$ at room temperature. For SEM, postfixed cells were dehydrated using a series of ethanol washes $(15,30,50,70,80,90,95$, and $100 \%)$, criticalpoint dried in $\mathrm{CO}_{2}$, coated with gold, then examined using a JEOL, 6510 scanning electron microscope (JEOL, 6510 series, Japan) [57].

\section{Reverse transcriptase quantitative polymerase chain reaction (RT-qPCR)}

After the biofilms were grown as described before, strong biofilm producer $S$. agalactiae isolates (code Nos. 3 and 10 in Table 2) were exposed separately to the $\mathrm{MBIC}_{50}$ of cinnamon oil $(2,4 \mu \mathrm{g} / \mathrm{mL}), \operatorname{AgNPs}(32$, $64 \mu \mathrm{g} / \mathrm{mL})$ and their combination $(1 / 2,8 / 16 \mu \mathrm{g} / \mathrm{mL})$, respectively, then incubated at $37^{\circ} \mathrm{C}$ for $12 \mathrm{~h}$. S. agalactiae biofilm producers receiving no treatments served as controls. The biofilms were carefully harvested and gently washed with PBS to remove nonadherent cells. Total RNA was extracted from biofilms of treated and non-treated $S$. agalactiae isolates using a QIAamp RNeasy Mini kit (Qiagen, Germany) following the manufacturer's instructions. The relative expression levels of pili biosynthesis genes [pilA (sag1407) and pilB (sag1408)], and their regulator $(\operatorname{rog} B)$ [23] were determined by one-step RT-qPCR using QuantiTect SYBR Green RT-PCR Kit (Qiagen, Germany) in the MX3005P real-time PCR thermal cycler (Stratagene, La Jolla, CA, USA) according to the manufacturer's instructions. Each sample was subjected to RT-qPCR in triplicate, and the mean values were used for subsequent analysis. Oligonucleotide primer pairs used in the RT-qPCR technique are listed in Additional File 2. The specificity of the amplified products was verified by generating melting curves (one cycle of $94^{\circ} \mathrm{C}$ for $1 \mathrm{~min}, 50^{\circ} \mathrm{C}$ for $1 \mathrm{~min}$, and $94{ }^{\circ} \mathrm{C}$ for $1 \mathrm{~min}$ for each pilA, pilB, and $\operatorname{rog} B$ genes). The relative expression levels of the tested genes were normalized to the constitutive expression of the $\operatorname{gyr} A$ housekeeping gene. The fold changes in the transcript levels of targeted genes in treated S. agalactiae biofilm producers relative to their levels in the untreated ones were calculated according to the comparative $2^{-\Delta \Delta C T}$ method [61].

\section{Bioinformatics and statistical analyses}

The data were analyzed by one-way analysis of variance (ANOVA) [62], and the P-value of $<0.05$ was considered statistically different. The differences between means were detected by Duncan's multiple range test [63]. Correlation analysis was performed using Pearson's correlation test according to the CORR procedure. These analyses were performed using Statistical Package for Social Sciences (SPSS; v. 25, IBM, United States). For each antimicrobial compound understudy, the average percentage of biofilm inhibition was shown as mean \pm standard error. The number of isolates showing certain $\mathrm{MBIC}_{50}$ was plotted for each compound. Student $t$-test (unpaired, twotailed) was used to determine if there were significant differences between the $\mathrm{MBIC}_{50}$ of $S$. agalactiae isolates exposed to each antimicrobial compound. These analyses were done using GraphPad Prism version 8 for Windows, San Diego California USA, www. graphpad.com.

\section{Nucleotide sequence accession numbers}

The tuf gene nucleotide sequences generated in the current study were deposited into the GenBank under accession numbers MW133069-MW133082.

\section{Abbreviations}

ANOVA: Analyses of variance; CAMP: Christie, Atkins, and Munch-Petersen; CFU: Colony-forming unit; CLSI: Clinical and Laboratory Standards Institute; DMSO: Dimethyl sulfoxide; $\Sigma$ FIC: Fractional inhibitory concentration index; MAR: Multiple antibiotic resistance; MBC: Minimum bactericidal concentration; MBIC: Minimum biofilm inhibitory concentration; MDR: Multidrug-resistant; MIC: Minimum inhibitory concentration; OD: Optical density; PCR: Polymerase chain reaction; RT-qPCR: Reverse transcriptase quantitative polymerase chain reaction; SEM: Scanning electron microscopy; TSA: Tryptic soy agar; TSB: Tryptic soy broth

\section{Supplementary Information}

The online version contains supplementary material available at https://doi. org/10.1186/s12917-021-02842-9.

Additional file 1. Scanning electron micrographs of S. agalactiae biofilms on the 96-well microtitre plate after exposure to the $\mathrm{MBIC}_{50}$ of the antimicrobial compounds. A) Untreated S. agalactiae biofilm producer, B) cells treated with cinnamon oil $(2 \mu \mathrm{g} / \mathrm{mL}), C)$ cells treated with silver nanoparticles $(32 \mu \mathrm{g} / \mathrm{mL})$, D) cells treated with cinnamon oil silver nanoparticles combination $(1 / 2 \mu \mathrm{g} / \mathrm{mL})$. The biofilm appears as electrondense materials around bacterial cells. Treatment of biofilm-producing isolates with $B, C$, or $D$ resulted in the detachment of the biofilms with various degrees. The magnification power is 2500x; scale bars $=10 \mathrm{~nm}$.

Additional file 2. Oligonucleotide primer sequences used for PCR assays. 


\section{Acknowledgments}

Not applicable.

\begin{abstract}
Authors' contributions
NKA, AMA, and EYE contributed in the conception and design of the study. NKA, AAE, and HME carried out the classical microbiological techniques and molecular genetic studies. AAH, AS, and IEE participated with NKA and HME in analysis and interpretation of data. NKA and HME wrote the initial draft of the manuscript; and revised it critically for important intellectual content. All authors revised the manuscript and approved it for publication.
\end{abstract}

\section{Funding}

Not applicable.

\section{Availability of data and materials}

The tuf gene nucleotide sequences generated in the current study were deposited into the GenBank under accession numbers MW133069MW133082.

All data generated or analyzed during this study are included in this manuscript and its additional files. The datasets analyzed in the current study are available on request from the corresponding author.

\section{Declarations}

\section{Ethics approval and consent to participate}

Recruitment of dairy cows into this work was done in consultation with the veterinarians, and sampling was performed after the permission of the dairy farms' owners in written consent. Every individual was provided with a document explaining the purpose and method of sample collection. The study was approved by the committee of Animal Welfare and Research Ethics, Faculty of Veterinary Medicine, Zagazig University, Egypt.

\section{Consent for publication}

Not applicable.

\section{Competing interests}

The authors declare that they have no competing interests.

\section{Author details}

'Department of Microbiology, Faculty of Veterinary Medicine, Zagazig University, Zagazig, Sharkia 44511, Egypt. ²Department of Animal Medicine, Infectious Diseases, Faculty of Veterinary Medicine, Zagazig University, Zagazig, Sharkia, Egypt. ${ }^{3}$ Abou Hamad Veterinary Organizations, Ministry of Agriculture, Abou Hamad, Sharkia, Egypt. ${ }^{4}$ Veterinary Hospital, Faculty of Veterinary Medicine, Zagazig University, Zagazig, Sharkia, Egypt. ${ }^{5}$ Department of Microbiology, Veterinary Hospital, Faculty of Veterinary Medicine, University of Sadat City, Sadat City, Egypt. ${ }^{6}$ Department of Bacteriology, Mycology and Immunology, Faculty of Veterinary Medicine, Kafrelsheikh University, Kafrelsheikh, Egypt.

\section{Received: 29 April 2020 Accepted: 18 March 2021}

Published online: 31 March 2021

\section{References}

1. Patterson MJ. Streptococcus. In: Baron S, editor. Medical Microbiology. 4th ed. Galveston (TX): University of Texas Medical Branch at Galveston; 1996. Chapter 13.

2. Andersen HJ, Pedersen LH, Aarestrup FM, Chriél M. Evaluation of the surveillance program of Streptococcus agalactiae in Danish dairy herds. J Dairy Sci. 2003;86(4):1233-9. https://doi.org/10.3168/jds.S0022-0302(03)73 707-2.

3. Halasa $T$, Huijps $K$, Østerås $O$, Hogeveen $H$. Economic effects of bovine mastitis and mastitis management: a review. Vet Q. 2007;29(1):18-31. https://doi.org/10.1080/01652176.2007.9695224.

4. Pang M, Sun L, HeT BH, Zhang L, Zhou Y, Zhang H, et al. Molecular and virulence characterization of highly prevalent Streptococcus agalactiae circulated in bovine dairy herds. Vet Res. 2017;48(1):65. https://doi.org/10.11 86/s13567-017-0461-2.

5. Jørgensen HJ, Nordstoga AB, Sviland S, Zadoks RN, Sølverød L, Kvitle B, et al. Streptococcus agalactiae in the environment of bovine dairy herds--rewriting the textbooks? Vet Microbiol. 2016;184:64-72. https://doi.org/10.1016/j. vetmic.2015.12.014.

6. Almeida A, Alves-Barroco C, Sauvage E, Bexiga R, Albuquerque P, Tavares F, et al. Persistence of a dominant bovine lineage of group B streptococcus reveals genomic signatures of host adaptation. Environ Microbiol. 2016; 18(11):4216-29. https://doi.org/10.1111/1462-2920.13550.

7. Saed HAR, Ibrahim HMM. Antimicrobial profile of multidrug- resistant Streptococcus spp. isolated from dairy cows with clinical mastitis. J Adv Vet Anim Res. 2020;7(2):186-97. https://doi.org/10.5455/javar.2020.g409.

8. Eldesouky IE, Refae MA, Nada HS, Hassb Elnaby GR. Molecular detection of Streptococcus species isolated from cows with mastitis. World Vet. 2016;6: 193-202. https://doi.org/10.5455/wvj.20161085.

9. Boonyayatra S, Pata P, Nakharuthai P, Chaisri W. Antimicrobial resistance of biofilm-forming Streptococcus agalactiae isolated from bovine mastitis. J Vet Sci Technol. 2016;7(5):1-5. https://doi.org/10.4172/2157-7579.1000374.

10. Kaczorek E, Małaczewska J, Wójcik R, Siwicki AK. Biofilm production and other virulence factors in Streptococcus spp isolated from clinical cases of bovine mastitis in Poland. BMC Vet Res. 2017;13(1):398. https://doi.org/10.11 86/s12917-017-1322-y.

11. Melchior MB, Vaarkamp H, Fink-Gremmels J. Biofilms: a role in recurrent mastitis infections? Vet J. 2006;171(3):398-407. https://doi.org/10.1016/j.tvjl.2 005.01.006.

12. Felipe $\mathrm{V}$, Morgante CA, Somale PS, Varroni F, Zingaretti ML, Bachetti RA, et al. Evaluation of the biofilm forming ability and its associated genes in Staphylococcus species isolates from bovine mastitis in Argentinean dairy farms. Microb Pathog. 2017;104:278-86. https://doi.org/10.1016/j.micpath.2 017.01.047.

13. Keefe G. Update on control of Staphylococcus aureus and Streptococcus agalactiae for management of mastitis. Vet cli North Am Food Anim Pract. 2012;28(2):203-16. https://doi.org/10.1016/j.cvfa.2012.03.010.

14. Ding Y, Zhao J, He X, Li M, Guan H, Zhang Z, et al. Antimicrobial resistance and virulence-related genes of streptococcus obtained from dairy cows with mastitis in Inner Mongolia, China. Pharmaceutical Biol. 2016;54(1):1627. https://doi.org/10.3109/13880209.2015.1025290.

15. Mushtaq S, Shah AM, Shah A, Lone SA, Hussain A, Hassan QP, et al. Bovine mastitis: an appraisal of its alternative herbal cure. Microb Pathog. 2018;114: 357-61. https://doi.org/10.1016/j.micpath.2017.12.024.

16. Gill AO, Holley RA. Mechanisms of bactericidal action of cinnamaldehyde against Listeria monocytogenes and of eugenol against L. monocytogenes and Lactobacillus sakei. Appl Environ Microbiol 2004; 70: 5750-5755. https:// doi.org/https://doi.org/10.1128/AEM.70.10.5750-5755.2004, 10.

17. Theophel K, Schacht VJ, Schlüter M, Schnell S, Stingu CS, Schaumann R, et al. The importance of growth kinetic analysis in determining bacterial susceptibility against antibiotics and silver nanoparticles. Front Microbiol. 2014;5:1-10. https://doi.org/10.3389/fmicb.2014.00544.

18. Dakal TC, Kumar A, Majumdar RS, Yadav V. Mechanistic basis of antimicrobial actions of silver nanoparticles. Front Microbiol. 2016;7:1831. https://doi.org/10.3389/fmicb.2016.01831.

19. Norhan K, El-Aziz A, Abd El-Hamid MI, Bendary MM, El-Azazy AA, Ammar AM. Existence of vancomycin resistance among methicillin resistant $S$. aureus recovered from animal and human sources in Egypt. Slov Vet Res. 2018;55(Suppl 20):221-30. https://doi.org/10.26873/SVR-649-2018.

20. Sserunkuma P, McGaw LJ, Nsahlaia IV, Van Stadenb J. Selected southern African medicinal plants with low cytotoxicity and good activity against bovine mastitis pathogens. S Afr J Bot. 2017;111:242-7. https://doi.org/10.1 016/j.sajb.2017.03.032.

21. Shome BR, Bhuvana M, Mitra SD, Krithiga N, Shome R, Velu D, et al. Molecular characterization of Streptococcus agalactiae and Streptococcus uberis isolates from bovine milk. Trop Anim Health Prod. 2012:44(8):1981-92. https://doi.org/10.1007/s11250-012-0167-4.

22. Gangwal A, Kashyap SK. Identification of bovine mastitis associated pathogens by multiplex PCR. Dairy and Vet Sci J. 2017;3(5):555622. https:// doi.org/10.19080/JDVS.2017.03.555622.

23. Gutekunst H, Eikmanns BJ, Reinscheid DJ. Analysis of RogB-controlled virulence mechanisms and gene expression in Streptococcus agalactiae. Infect Immun. 2003;71(9):5056-64. https://doi.org/10.1128/iai.71.9.50565064.2003.

24. El-Behiry A, Elsayed M, Marzouk E, Bathich Y. Detection of virulence genes in Staphylococcus aureus and Streptococcus agalactiae isolated from mastitis in the Middle East. Br Microbiol Res J. 2015;10(3):1-9. https://doi.org/10.9734/ BMRJ/2015/19237. 
25. Sukhnanand S, Dogan B, Ayodele MO, Zadoks RN, Craver MP, Dumas NB, et al. Molecular subtyping and characterization of bovine and human Streptococcus agalactiae isolates. J Clin Microbiol. 2005;43(3):1177-86. https://doi.org/10.1128/JCM.43.3.1177-1186.2005.

26. Malinowski E, Lassa H, Smulski S, Kłossowska A, Kaczmarowski M. Antimicrobial susceptibility of bacteria isolated from cows with mastitis in 2006-2007. Bull Vet Inst Pulawy. 2008;52:565-72.

27. Ananda Baskaran S, Kazmer GW, Hinckley L, Andrew SM, Venkitanarayanan K. Antibacterial effect of plant-derived antimicrobials on major bacterial mastitis pathogens in vitro. J Dairy Sci. 2009;92(4):1423-9. https://doi.org/1 $0.3168 /$ jds.2008-1384.

28. Lakehal S, Meliani A, Benmimoune S, Bensouna SN, Benrebiha FZ, Chaouia C. Essential oil composition and antimicrobial activity of Artemisia herbaalba Asso grown in Algeria. Med Chem (Los Angeles). 2016;6:435-9. https:// doi.org/10.4172/2161-0444.1000382

29. Dur'an N, Marcato PD, De Conti R, Alves OL, FTM C, Brocchi M. Potential use of silver nanoparticles on pathogenic bacteria, their toxicity and possible mechanisms of action. J Brazi Chem Soc. 2010;21:949-59. https://doi.org/1 0.1590/S0103-50532010000600002.

30. Rai M, Paralikar P, Jogee P, Agarkar G, Ingle AP, Derita M, et al. Synergistic antimicrobial potential of essential oils in combination with nanoparticles: emerging trends and future perspectives. Int J Pharm. 2017;519(1-2):67-78 https://doi.org/10.1016/j.ijpharm.2017.01.013.

31. Ghosh IN, Patil SD, Sharma TK, Srivastava SK, Pathania R, Navani NK. Synergistic action of cinnamaldehyde with silver nanoparticles against spore-forming bacteria: a case for judicious use of silver nanoparticles for antibacterial applications. Int J Nanomedicine. 2013;8:4721-31. https://doi. org/10.2147/IJN.S49649.

32. Otter JA, Vickery K, Walker JT, de Lancey Pulcini E, Stoodley P, Goldenberg SD, et al. Surface-attached cells, biofilms and biocide susceptibility: implications for hospital cleaning and disinfection. J Hosp Infect. 2015;89: 16-27. https://doi.org/10.1016/j.jhin.2014.09.008.

33. Ansari MA, Khan HM, Khan AA, Cameotra SS, Saquib Q, Musarrat J. Gum arabic capped-silver nanoparticles inhibit biofilm formation by multi-drug resistant strains of Pseudomonas aeruginosa. J Basic Microbiol. 2014;54(7): 688-99. https://doi.org/10.1002/jobm.201300748.

34. Yu L, Shang F, Chen X, Ni J, Yu L, Zhang M, et al. The anti-biofilm effect of silver-nanoparticle-decorated quercetin nanoparticles on a multi-drug resistant Escherichia coli strain isolated from a dairy cow with mastitis. Peer J. 2018;6:e5711. https://doi.org/10.7717/peerj.5711.

35. National Mastitis Council. Laboratory handbook on bovine mastitis. Madison, Wl: National Mastitis Council; 1999

36. Quinn PJ, Carter ME, Markey B, Carter GR. Clinical Veterinary Microbiology. London: Mosby; 1999. p. 21-66.

37. Domig KJ, Mayer HK, Kneifel W. Methods used for the isolation, enumeration, characterization and identification of Enterococcus spp. 2. Pheno- and genotypic criteria. Int J Food Microbiol. 2003;88:165-88. https:// doi.org/10.1016/s0168-1605(03)00178-8.

38. Hardie JM. Genus Streptococcus. In: PHA S, editor. Bergey's Manual of Systematic Bacteriology. Vol 2. Baltimore: Williams and Wilkins; 1986. p. 1043-71.

39. Spellerberg B. Laboratory Diagnosis of Streptococcus pyogenes (group A streptococci). In: Ferretti JJ, Stevens DL, Fischetti VA, editors. treptococcus pyogenes: Basic biology to clinical manifestations. Oklahoma City: University of Oklahoma Health Sciences Center; 2016.

40. Christie R, Atkins NE, Munch-Petersen E. A note on a lytic phenomenon shown by group B streptococci. Aust J Exp Biol Med Sci. 1944;22(3):197-200. https://doi.org/10.1038/icb.1944.26.

41. Bauer AW, Kirby WM, Sherris JC, Turck M. Antibiotic susceptibility testing by a standard single disc method. Am J Clin Pathol. 1966;45(4_ts):493-6. https://doi.org/10.1093/ajcp/45.4_ts.493.

42. Clinical and Laboratory Standards Institute (CLSI). Performance standards for antimicrobial susceptibility testing. 27th ed. Wayne, PA; 2017. p. M100-S27.

43. Tambekar D, Dhanorkar D, Gulhane S, Khandelwal V, Dudhane M. Antibacterial susceptibility of some urinary tract pathogens to commonly used antibiotics. Afr J Biotechnol. 2006;5:1562-5.

44. Picard FJ, Ke D, Boudreau DK, Boissinot M, Huletsky A, Richard D, et al. Use of tuf sequences for genus-specific PCR detection and phylogenetic analysis of 28 streptococcal species. J Clin Microbiol. 2004;42(8):3686-95. https://doi. org/10.1128/JCM.42.8.3686-3695.2004
45. Ke D, Ménard C, Picard FJ, Boissinot M, Ouellette M, Roy PH, et al. Development of conventional and real-time PCR assays for the rapid detection of group B streptococci. Clin Chem. 2000;46(3):324-31. https://doi. org/10.1093/clinchem/46.3.324.

46. Bergseng $H$, Bevanger $L$, Rygg $M$, Bergh K. Real-time PCR targeting the sip gene for detection of group $B$ streptococcus colonization in pregnant women at delivery. J Med Microbiol. 2007;56(2):223-8. https://doi.org/10.1 099/jmm.0.46731-0.

47. Nithin Prabhu K, Isloor SK, Hegde R, Suryanarayana W. Standardization of $P C R$ and phylogenectic analysis for predominant streptococcal species isolated from subclinical mastitis, vol. 50. Bikaner, Rajasthan: International Symposium on "Role of biotechnology in conserving biodiversity and livestock development for food security and poverty alleviation" and XVIIth Annual Convention of Indian Society of Veterinary Immunology \& Biotechnology (ISVIB); 2010. p. 47.

48. Dmitriev A, Suvorov A, Shen AD, Yang YH. Clinical diagnosis of group B streptococci by scpB gene based PCR. Indian J Med Res. 2004;119(Suppl):233-6.

49. Wastfelt M, Stalhammar-Carlemalm M, Delisse AM, Cabezon T, Lindahl G. Identification of a family of streptococcal surface proteins with extremely repetitive structure. J Biol Chem. 1996;271(31):18892-7. https://doi.org/10.1 074/jbc.271.31.18892.

50. Al Safadi R, Amor S, Hery-Arnaud G, Spellerberg B, Lanotte P, Mereghetti L, et al. Enhanced expression of Imb gene encoding laminin-binding protein in Streptococcus agalactiae strains harboring IS1548 in scpB-Imb intergenic region. PLoS One. 2010;5(5):e10794. https://doi.org/10.1371/journal.pone.0010794.

51. Valgas C. Machado de Souza S, Smânia EFA, Smânia AJR. Screening methods to determine antibacterial activity of natural products. Braz J Microbiol. 2007;38(2):369-80. https://doi.org/10.1590/s1517-838220070002 00034.

52. Choi O, Choi SK, Kim J, Park CG, Kim J. In vitro antibacterial activity and major bioactive components of Cinnamomum verum essential oils against cariogenic bacteria, Streptococcus mutans and Streptococcus sobrinus. Asian Pac J Trop Biomed. 2016;6(4):308-14. https://doi.org/10.1016/j.apjtb.2016.01.007.

53. Rankin DI. Test methods: MIC testing. In: Coyle BM, editor. Manual of Antimicrobial Susceptibility Testing, American Society for Microbiology; 2005. p. 53-62.

54. Hamilton-Miller JMT. Calculating MIC50. J Antimicrob Chemother. 1991; 27(6):863-75. https://doi.org/10.1093/jac/27.6.863.

55. Filoche SK, Som K, Sissons CH. Antimicrobial effects of essential oils in combination with chlorhexidine digluconate. Oral Microbiol Immunol. 2005; 20(4):221-5. https://doi.org/10.1111/j.1399-302X.2005.00216.X.

56. Odds FC. Synergy, antagonism, and what the chequerboard puts between them. J Antimicrob Chemother. 2003;52(1):1. https://doi.org/10.1093/jac/ dkg301.

57. Biasi-Garbin RP, Saori Otaguiri E, Morey A, Fernandes da Silva M, Belotto Morguette AE, Armando Contreras Lancheros C, et al. Effect of eugenol against Streptococcus agalactiae and synergistic interaction with biologically produced silver nanoparticles. Evid-Based Complementary Altern Med. 2015; 2015:1-8. https://doi.org/10.1155/2015/861497.

58. Tendolkar PM, Baghdayan AS, Gilmore MS, Shankar N. Enterococcal surface protein, Esp, enhances biofilm formation by Enterococcus faecalis. Infect Immun. 2004;72(10):6032-9. https://doi.org/10.1128/IAI.72.10.6032-6039.2004.

59. Stepanović S, Vuković D, Hola V, Di Bonaventura G, Djukić S, Cirković I, et al. Quantification of biofilm in microtiter plates: overview of testing conditions and practical recommendations for assessment of biofilm production by staphylococci. Acta Pathol Microbiol Immunol Scand. 2007;115(8):891-9. https://doi.org/10.1111/j.1600-0463.2007.apm_630.x.

60. Raja A, Ali F, Khan I. Anti-staphylococcal and biofilm inhibitory activities of acetyl-11-keto- $\beta$-boswellic acid from Boswellia serrate. BMC Microbiol. 2011; 11(1):1-9. https://doi.org/10.1186/1471-2180-11-54.

61. Livak KJ, Schmittgen TD. Analysis of relative gene expression data using real-time quantitative PCR and the 2(-Delta Delta C (T)) method. Methods. 2001;25(4):402-8. https://doi.org/10.1006/meth.2001.1262.

62. Snedecor GW, Cochran WG. Statistical Methods. 6th Ed. lowa State Univ. Press, Ames, USA; 1982.

63. Duncan DB. Multiple range and multiple F-tests. Biometrics. 1955;11(1):1-24. https://doi.org/10.2307/3001478.

\section{Publisher's Note}

Springer Nature remains neutral with regard to jurisdictional claims in published maps and institutional affiliations. 